\title{
Presence and Reduction of Anthropogenic Substances with UV Light and Oxidizing Disinfectants in Wastewater-A Case Study at Kuopio, Finland
}

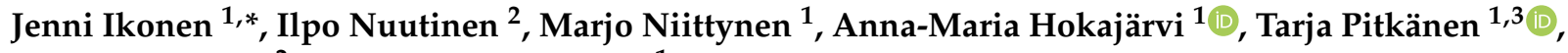 \\ Eero Antikainen ${ }^{2}$ and Ilkka T. Miettinen ${ }^{1}$ \\ 1 Water Microbiology Laboratory, Department of Health Security, Finnish Institute for Health and Welfare, \\ P.O. Box 95, FI-70701 Kuopio, Finland; marjo.niittynen@thl.fi (M.N.); anna-maria.hokajarvi@thl.fi (A.-M.H.); \\ tarja.pitkanen@thl.fi (T.P.); ilkka.miettinen@thl.fi (I.T.M.) \\ 2 School of Engineering and Technology, Savonia University of Applied Sciences, P.O. Box 6 (Microkatu 1), \\ FI-70201 Kuopio, Finland; ilpo.nuutinen@savonia.fi (I.N.); eero.antikainen@savonia.fi (E.A.) \\ 3 Faculty of Veterinary Medicine, Department of Food Hygiene and Environmental Health, \\ University of Helsinki, P.O. Box 66, FI-00014 Helsinki, Finland \\ * Correspondence: jenni.ikonen@thl.fi; Tel.: +358-29-524-6375
}

check for updates

Citation: Ikonen, J.; Nuutinen, I.; Niittynen, M.; Hokajärvi, A.-M.; Pitkänen, T.; Antikainen, E.; Miettinen, I.T. Presence and Reduction of Anthropogenic Substances with UV Light and Oxidizing Disinfectants in Wastewater-A Case Study at Kuopio, Finland. Water 2021, 13, 360. https://doi.org/10.3390/w13030360

Academic Editor: Amin Mojiri Received: 18 December 2020

Accepted: 27 January 2021

Published: 30 January 2021

Publisher's Note: MDPI stays neutral with regard to jurisdictional claims in published maps and institutional affiliations.

Copyright: (c) 2021 by the authors. Licensee MDPI, Basel, Switzerland. This article is an open access article distributed under the terms and conditions of the Creative Commons Attribution (CC BY) license (https:// creativecommons.org/licenses/by/ $4.0 /)$.

\begin{abstract}
Anthropogenic substances are a major concern due to their potential harmful effects towards aquatic ecosystems. Because wastewater treatment plants (WWTPs) are not designed to remove these substances from wastewater, a part of the anthropogenic substances enter nature via WWTP discharges. During the spring 2019, the occurrence of anthropogenic substances in the municipal wastewater effluent in Kuopio, Finland, was analysed. Furthermore, the capacity of selected disinfection methods to reduce these substances from wastewater was tested. The disinfection methods were ozonation $\left(760 \mathrm{~mL} \mathrm{~min}^{-1}\right)$ with an OxTube hermetic dissolution method (1), the combined usage of peracetic acid (PAA) $\left(<5 \mathrm{mg} \mathrm{L}^{-1}\right)$ and ultraviolet (UV) disinfection $\left(12 \mathrm{~mJ} / \mathrm{cm}^{2}\right)(2)$, and the combined usage of hydrogen peroxide $\left(\mathrm{H}_{2} \mathrm{O}_{2}\right)\left(<10 \mathrm{mg} \mathrm{L}^{-1}\right)$ and UV disinfection (12 mJ/ $\mathrm{cm}^{2}$ ) (3). The substances found at the concentrations over $1 \mu \mathrm{g} \mathrm{L}^{-1}$ in effluent $(\mathrm{N}=3)$ were cetirizine $\left(5.2 \pm 1.3 \mu \mathrm{g} \mathrm{L}^{-1}\right)$, benzotriazole (BZT) $\left(2.1 \pm 0.98 \mu \mathrm{g} \mathrm{L}^{-1}\right)$, hydrochlorothiazide $\left(1.7 \pm 0.2 \mu \mathrm{g} \mathrm{L}^{-1}\right)$, furosemide $\left(1.6 \pm 0.2 \mu \mathrm{g} \mathrm{L}^{-1}\right)$, lamotrigine $\left(1.5 \pm 0.06 \mu \mathrm{g} \mathrm{L}^{-1}\right)$, diclofenac (DCF) $\left(1.4 \pm 0.2 \mu \mathrm{g} \mathrm{L}^{-1}\right)$, venlafaxine $\left(1.0 \pm 0.13 \mu \mathrm{g} \mathrm{L}^{-1}\right)$ and losartan $\left(0.9 \pm 0.2 \mu \mathrm{g} \mathrm{L}^{-1}\right)$. The reduction $(\%)$ with different methods $(1,2,3)$ were: cetirizine $(99.9,5.0, \mathrm{NR}=$ no removal), benzotriazole $(67.9$, NR, NR), hydrochlorothiazide (91.1, 5.9, NR), furosemide (99.7, 5.9, NR), lamotrigine (46.4, NR, 6.7), diclofenac $(99.7,7.1,16.7)$, venlafaxine $(91.3, \mathrm{NR}, 1.1)$, losartan $(99.6,13.8, \mathrm{NR})$. Further research concerning the tested disinfection methods is needed in order to fully elucidate their potential for removing anthropogenic substances from purified wastewater.
\end{abstract}

Keywords: anthropogenic substances; disinfection; wastewater

\section{Introduction}

Emerging anthropogenic pollutants are a permanent global challenge to freshwater quality and safety [1-3]. A major group of emerging pollutants in the aquatic environmental consists of pharmaceuticals [4]. After being used for human or animal medication [5], pharmaceuticals are mainly excreted in urine and faeces as such or as metabolites [6]. Subsequently, they are distributed in the environment via wastewater treatment plants (WWTPs) [7] where they pass through various treatment processes and, therefore, are easily transferred to the receiving waters. In Finland, the legislation does not require the removal of anthropogenic substances from wastewater before discharge into the environment and most of the treated wastewaters are discharged to the receiving waters without disinfection. The Water Framework Directive (WFD) [8] aimed to improve the status of all European 
Union (EU) inland waters, coastal waters, and groundwater by 2015. The deadline has been extended until 2027 at the latest under the WFD derogation rules.

In the future, the use of pharmaceuticals is likely to increase due to the ageing population. Unless efforts are made to reduce emissions, more pharmaceutical residues will end up in the environment. To compare the effectiveness of different wastewater treatment methods, more research data on the existence and harmfulness of these substances in the environment is needed. EU Member States are required to monitor the concentrations of 45 substances or groups of substances in the aquatic environment [9]. These substances are listed in the directive 2013/39/EU (amending Directives 2000/60/EC and 2008/105/EC as regards priority substances in the field of water policy). Moreover, some of the substances are listed as priority hazardous substances. Furthermore environmental quality standards (EQS) are included in the directive for these 45 substances or groups of substances that EU Member States are required to monitor. The concentrations of the substances in water or biota must not exceed the EQS set for them. With the aim of achieving good surface water chemical status, the revised EQS for existing priority substances should be met by the end of 2021 and the EQS for newly identified priority substances by the end of 2027.

At the WWTPs pharmaceuticals may transform, retain in sewage sludge, or end up in receiving water. In a recent risk assessment study concerning Finnish surface waters, the calculated environmental risk was assessed by a so called risk component; or risk quotient (RQ). A risk quotient $>1$ was found for 29 of the evaluated substances, suggesting that these substances potentially pose a risk in Finnish surface waters. Four substances: diclofenac (DCF) $\left(0.022 \mu \mathrm{g} \mathrm{L}^{-1}\right)$, azithromycin $\left(0.0015 \mu \mathrm{g} \mathrm{L}^{-1}\right)$, ciprofloxacin $\left(0.034 \mu \mathrm{g} \mathrm{L}^{-1}\right)$, and $17 \alpha$ - ethinylestradiol $\left(0.00018 \mu \mathrm{g} \mathrm{L}^{-1}\right)$ concentrations measured in Finnish surface waters exceeded concentrations assessed as harmful [10].

As the pharmaceuticals and other anthropogenic substances are not properly removed in current WWTP processes, alternative, tentatively more efficient removal options such as novel disinfection methods to remove these substances from wastewater have been studied. For example in Mexico, Mejía-Morales et al. studied a post treatment with advanced oxidation process (AOP) based on an ultraviolet (UV) $/ \mathrm{H}_{2} \mathrm{O}_{2} / \mathrm{O}_{3}$ system in hospital wastewaters [11]. In addition, various other methods have been tested to remove inorganic and organic impurities from water such as porous ceramic disk filter (PVDF) ultrafiltration membrane [12] and porous ceramic disk filter coated with $\mathrm{Fe} / \mathrm{TiO} 2$ nano-composites [13]. Here we studied the efficiency of three disinfection methods, i.e., ozonation $\left(760 \mathrm{~mL} \mathrm{~min}^{-1}\right)$ with OxTube mixing; a combination of peracetic acid (PAA) $\left(<5 \mathrm{mg} \mathrm{L}^{-1}\right)$ and UV disinfection $\left(12 \mathrm{~mJ} / \mathrm{cm}^{2}\right)$, and a combination of hydrogen peroxide $\left(<10 \mathrm{mg} \mathrm{L}^{-1}\right)$ and UV disinfection $\left(12 \mathrm{~mJ} / \mathrm{cm}^{2}\right)$ in order to reduce the amount of anthropogenic substances in treated wastewater. This study was one part of a project in which we studied the removal of certain microbes and chemicals in different water matrices with different disinfection methods.

\section{Materials and Methods}

Treated wastewater samples $(\mathrm{N}=3)$ were collected from the municipal WWTP of the city of Kuopio (Lehtoniemi WWTP) in the spring of 2019. The wastewater that was used in the tests was from the channel where purified wastewater is discharged into the surface water. The population of the service area of the Lehtoniemi WWTP is 90,697; and the total population of the city of Kuopio is 118,000 . The disinfection methods tested herein were an ozone purification process with the OxTube hermetic dissolution method, a combination of the usage of PAA $\left(<5 \mathrm{mg} \mathrm{L}^{-1}\right)$ and UV disinfection $\left(12 \mathrm{~mJ} / \mathrm{cm}^{2}\right)$ processes, and a combination of hydrogen peroxide $\left(<10 \mathrm{mg} \mathrm{L}^{-1}\right)$ and UV disinfection $\left(12 \mathrm{~mJ} / \mathrm{cm}^{2}\right)$ processes. A wide set of chemical substances were analysed $(\mathrm{N}=121)$. Wastewater samples were taken before and after each disinfection treatment. All wastewater samples were frozen and stored at $-20^{\circ} \mathrm{C}$ and subsequently sent to a commercial laboratory (Eurofins Environment Testing Finland Oy, Lahti) for analysis. Analysed substances are listed in the Table S1. The substances were analysed with the U.S. Environmental Protection Agency 
(EPA) method 1694. Method 1694 is used for determination of pharmaceuticals and personal care products (PPCPs) in multi-media environmental samples by high-performance liquid chromatography combined with tandem mass spectrometry (HPLC/MS/MS) using isotope dilution and internal standard quantitation techniques [14].

\section{Experimental Design}

All disinfection experiments were carried out in the Savonia Water laboratory (Savonia University of Applied Sciences, Kuopio, Finland). The experimental design is shown in the Supplementary Material (Figure S1). First, a 1000-litre food-grade plastic container was filled with $500 \mathrm{~L}$ of wastewater. The treated wastewater was mixed with an electric motor-operated water mixer to ensure the homogeneity of the sample water. After the wastewater was disinfected, it was collected into a plastic container with a capacity of 45 L (Curtec Ltd., Denmark). The pipe material used was a plastic water pipe with an inner diameter of $15 \mathrm{~mm}$ (Uponor Aqua Pipe, PEX 15/18 mm polyethylene, PE) and the connectors were acid-resistant stainless steel water pipe fittings (various manufacturers).

For the pumping of the tested wastewater, a $24 \mathrm{~V}$ resistance-adjustable gear pump designed for drinking water systems in boats with a maximum flow of $26 \mathrm{~L} \mathrm{~min}^{-1}$ (Marco UP/Em, Castenedolo, Italy,) was used. Acid-resistant steel valves (EGO, stainless) were used in the test system due to the oxidizing peroxide chemicals used in the experiments.

For the supply of peroxide chemicals (PAA and $\mathrm{H}_{2} \mathrm{O}_{2}$ ) (Lamor water technology, Finland), a chemical pump (Grundfos DDA 12-10 AR-PP/E/C-F-31U2U2FG, Bjerringbro, Denmark) with proven chemical supply and adjustability for a wide feed rate between $12 \mathrm{~mL} \mathrm{~h}^{-1}$ and $12 \mathrm{~L} \mathrm{~h}^{-1}$ was obtained. A rotameter (Kobold, Germany) with a flow scale of 100 to $1000 \mathrm{~L} \mathrm{~h}^{-1}$ was obtained to measure the water flow. A tube UV lamp (Wedeco Aquada 1, Xylem, Herford) was used in the disinfection experiments. A Faraday Ozone L 40 G (Farady Ozone, Coimbatore, India) device, which is capable of producing ozone with a capacity of $40.000 \mathrm{mg} \mathrm{h}^{-1}$, was used as the ozone generator. The flow of ozone gas was controlled with the mass flow controller (Brooks GF040). An OxTube water treatment tube (OxTubeDN20, Sansox Oy, Lahti, Finland) was used for mixing and dissolving ozone hermetically in the test water. The OxTube hermetic dissolution method (Figure 1) treats the water in flowing condition in its hermetic tube. The air gases are sucked by the vacuum effect in the nozzle zone and led directly into the middle of the main flow. Other gases like pure oxygen, ozone, $\mathrm{CO}_{2}$ as well as chemicals can be fed and dispensed through the same channel. The water and gases are mixed evenly and the meeting probability of the molecules is high. Chemical reactions follow immediately in the hermetic condition. There are four main functions following each other seamlessly in one tube or in separate modules by function. The water is clarified and dissolved with desirable ingredients, e.g., air gases in the tube within a second or less.

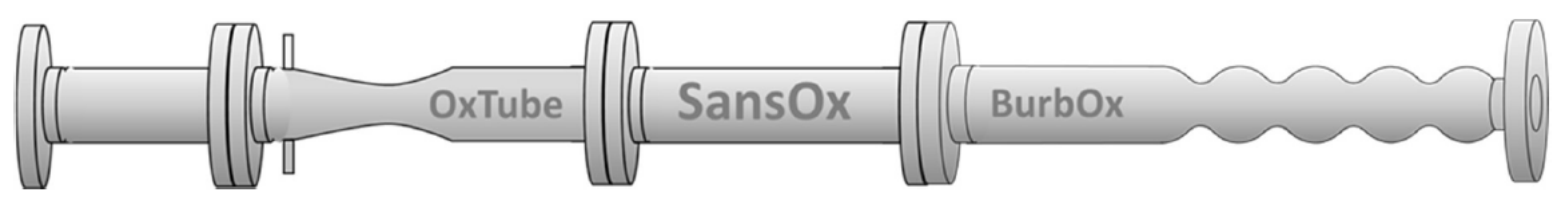

Figure 1. OxTube hermetic dissolution method (Sansox Oy, Lahti, Finland).

Chemical concentrations were measured using a Chemetrics Inc. V-2000 spectrometer (Chemetrics Inc., Midland, VA, USA) and suitable measuring ampoules including a Chemetrics K7913 for peracetic acid, K-5543 for hydrogen peroxide and K-7423 for ozone.

\section{Results and Discussion}

The anthropogenic substances with detected concentrations over $1 \mu \mathrm{g} \mathrm{L}^{-1}$ in the wastewater are shown in Table 1, as well as the removal efficiencies for the chemicals with the tested disinfection methods. The measurement uncertainty is between $45-51 \%$ in the analyses presented here. Each of the substances is discussed later in this manuscript. 
Anthropogenic substances detected concentrations below concentrations of $1 \mu \mathrm{g} \mathrm{L}-1$ in the wastewater are presented in the Supplemental Materials (Table S1).

Table 1. Anthropogenic substances with detected concentrations over $1 \mu \mathrm{g} \mathrm{L}{ }^{-1}$ in wastewater effluent and their removal efficiencies with the depicted methods.

\begin{tabular}{|c|c|c|c|c|c|c|c|}
\hline \multirow[t]{2}{*}{$\begin{array}{l}\text { Anthropogenic } \\
\text { Substance } \\
\text { (Intended Use) }\end{array}$} & \multicolumn{2}{|c|}{$\begin{array}{l}\text { Ozone and Ox Tube Device } \\
\qquad(\mathrm{N}=1)\end{array}$} & \multicolumn{2}{|c|}{$\begin{array}{l}\text { Peracetic Acid (PAA) and } \\
\text { Ultraviolet (UV) } \\
\text { Disinfection } \\
(\mathbf{N}=\mathbf{1})\end{array}$} & \multicolumn{2}{|c|}{$\begin{array}{l}\mathrm{H}_{2} \mathrm{O}_{2} \text { and UV Disinfection } \\
\qquad(\mathrm{N}=1)\end{array}$} & \multirow[t]{2}{*}{ EQS } \\
\hline & $\begin{array}{l}\text { Initial Con- } \\
\text { centration } \\
\left(\mu \mathrm{g} \mathrm{L}^{-1}\right)\end{array}$ & $\begin{array}{l}\text { Reduction } \\
(\%)\end{array}$ & $\begin{array}{l}\text { Initial Con- } \\
\text { centration } \\
\left(\mu \mathrm{g} \mathrm{L}^{-1}\right)\end{array}$ & $\begin{array}{l}\text { Reduction } \\
(\%)\end{array}$ & $\begin{array}{l}\text { Initial Con- } \\
\text { centration } \\
\left(\mu \mathrm{g} \mathrm{L}^{-1}\right)\end{array}$ & $\begin{array}{l}\text { Reduction } \\
(\%)\end{array}$ & \\
\hline $\begin{array}{c}\text { Cetirizine } \\
\text { (antihistamine) }\end{array}$ & 5.8 & 99.9 & 6.0 & 5.0 & 3.7 & - & NR \\
\hline $\begin{array}{l}\text { Benzotriazole } \\
\text { (chemical, } \\
\text { anticorrosive) }\end{array}$ & 2.8 & 67.9 & 2.5 & - & 0.98 & - & NR \\
\hline $\begin{array}{l}\text { Hydrochlorothiazide } \\
\text { (diuretic) }\end{array}$ & 1.8 & 91.1 & 1.7 & 5.9 & 1.5 & - & NR \\
\hline Furosemide (diuretic) & 1.8 & 99.7 & 1.7 & 5.9 & 1.4 & - & NR \\
\hline $\begin{array}{l}\text { Lamotrigine } \\
\text { (antiepileptic/ } \\
\text { antidepressant) }\end{array}$ & 1.4 & 46.4 & 1.5 & - & 1.5 & 6.7 & NR \\
\hline $\begin{array}{l}\text { Diclofenac (DCF) } \\
\text { (anti-inflammatory } \\
\text { medicine) }\end{array}$ & 1.5 & 99.7 & 1.4 & 7.1 & 1.2 & 16.7 & NR \\
\hline $\begin{array}{l}\text { Venlafaxine } \\
\text { (antidepressant) }\end{array}$ & 1.1 & 91.3 & 1.1 & - & 0.87 & 1.1 & NR \\
\hline $\begin{array}{l}\text { Losartan (used to treat } \\
\text { high blood pressure) }\end{array}$ & 1.2 & 99.6 & 0.8 & 13.8 & 0.84 & - & NR \\
\hline
\end{tabular}

- = no removal detected; NR = not regulated in Directive 2013/39/EU.

\subsection{Cetirizine}

Cetirizine is an ingredient that is used in the treatment of symptoms of seasonal allergic rhinitis [15], perennial allergic rhinitis, and chronic idiopathic urticarial in adults [16]. Unfortunately, cetirizine has been shown to induce adverse biochemical effects in the mussel Mytilus galloprovincialis and is thus problematic from the ecotoxicological point of view [17]. In our study, the concentration of cetirizine detected in the Kuopio wastewater effluent $\left(5.2 \pm 1.3 \mu \mathrm{g} \mathrm{L}^{-1}\right)$ clearly exceeds the concentrations reported earlier in Finland. The appearance and level of cetirizine in municipal wastewaters has previously been studied in the city of Turku in 2007 [7]. In that study cetirizine was found to be the dominating antihistamine in nearly all samples. The sampling included 12 influent and 12 effluent samples, and it was conducted between March and September. The highest detected concentration of cetirizine in that study was $0.22 \mu \mathrm{g} \mathrm{L}^{-1}$ (influent) and elimination rate of cetirizine in the sewage treatment process was 16\% [7]. Concentrations ranging from $0.1 \mu \mathrm{g} \mathrm{L}^{-1}$ to $0.7 \mu \mathrm{g} \mathrm{L}^{-1}$ have been detected in the influent of WWTPs in Berlin. Cetirizine levels were significantly increased between the hay season [18]. The concentration of this chemical is only slightly degraded during the wastewater treatment process [7]. For instance cetirizine removal from wastewater has been tested with granular activated carbon (GAC). Only 30.4\% of cetirizine was removed even when the contact time was 15 min with a GAC column [19]. The purification process with ozone and the OxTube hermetic dissolution method removed $99.9 \%$ of the cetirizine. The method consisting of PAA with UV disinfection was clearly less efficient, as it removed only $5 \%$. The third method (with a 
combination of $\mathrm{H}_{2} \mathrm{O}_{2}$ and UV) did not remove any of the cetirizine. The result obtained indicates that wastewater effluent disinfection with ozone is a very efficient method to remove cetirizine.

\subsection{Benzotriazoles (BZTs)}

Benzotriazoles (BZTs) are heterocyclic aromatic compounds that are widely used in industrial applications due to their excellent properties as corrosion inhibitors [20], antifreeze agents, and UV radiation stabilizers [21]. Another cause for the occurrence of BZTs in municipal wastewaters is their use in dishwasher products; tablets and powders [22]. BZTs are highly water soluble and highly polar compounds. In addition, they are moderately resistant against biological and photochemical degradation processes in the aquatic environment [23]. Moreover, BZTs have been identified in river water, groundwater, drinking water, wastewater as well as in soil, and in human samples. This is due to the low volatility of these compounds, their strong resistance to oxidation, and limited degradation under environmental conditions [24]. In our tests, the ozone purification process with the OxTube hermetic dissolution method removed $67.9 \%$ of the found BZT. PAA or $\mathrm{H}_{2} \mathrm{O}_{2}$ together with UV disinfection did not achieve removal efficiency. Loos et al. (2013) found that median concentrations of BZTs in an EU-wide wastewater treatment plant study were $2.7 \mu \mathrm{g} \mathrm{L}{ }^{-1}$ for $1 \mathrm{H}$-benzotriazole, and $2.1 \mu \mathrm{g} / \mathrm{L}$ for methylbenzotriazole (mixture of 4- and 5-isomers, also called tolyltriazoles), with maximum values up to $221 \mu \mathrm{g} \mathrm{L}^{-1}$ and $24.3 \mu \mathrm{g} \mathrm{L}^{-1}$, respectively. In our study concentrations of $2.1 \pm 0.98 \mu \mathrm{g} \mathrm{L}^{-1}$ of BZT in wastewater were detected (BZTs were not specified), which were median concentrations compared to concentrations measured in the EU [25]. Our study addresses the fact that when using ozone disinfecting for wastewater effluent, significant removal of BZT can be achieved.

\subsection{Hydrocholorothiazide}

Hydrochlorothiazide is a diuretic and an antihypertensive drug that is widely used by itself or in combination with other drugs for the treatment of edema and hypertension, as well as for other disorders such as diabetes insipidus, hypoparathyroidism, or hypercalciuria [26,27]. In Finland, hydrochlorothiazide concentrations of $1.8-6.7 \mu \mathrm{g} \mathrm{L}^{-1}$ have been reported in effluent wastewaters [28], which were on average higher than concentrations found in this study $(1.7 \pm 0.2 \mu \mathrm{g} \mathrm{L}-1)$. This compound has been frequently detected in the influents and effluents of WWTPs in Europe. In the Netherlands [29] concentrations of $1.27 \pm 0.26 \mu \mathrm{g} \mathrm{L}^{-1}$ (effluent) of hydrochlorothiazide were detected in municipal wastewater samples. In Spain, detected concentrations ranged between $2.5 \mu \mathrm{g} \mathrm{L}^{-1}$ and $14 \mu \mathrm{g} \mathrm{L}^{-1}$ in raw wastewater [30].

The removal of hydrochlorothiazide from wastewater has been studied using biological membranes in the laboratory and reduction percentages between $56 \%$ and $85 \%$ have been achieved. Slightly better removal has been achieved by conventional wastewater treatment [31]. In the present study, a removal rate of $91.1 \%$ was achieved with ozone purification using an OxTube hermetic dissolution method. With PAA and UV disinfection treatment, the removal was only $5.9 \%$. The combination of $\mathrm{H}_{2} \mathrm{O}_{2}$ and UV did not remove hydrochlorothiazide at all. Therefore, ozone disinfection was a superior method in terms of hydrochlorothiazide removal.

\subsection{Furosemide}

Furosemide, a diuretic that has been widely used since the 1960s, is poorly metabolized by humans [32]. In 2016, it was the most used diuretic in Finland [33]. The average concentration of furosemide detected in the Kuopio wastewater effluent $\left(1.6 \pm 0.2 \mu \mathrm{g} \mathrm{L}^{-1}\right)$ is slightly higher than concentrations detected before in Finland. A furosemide concentration of $1.4 \mu \mathrm{g} \mathrm{L}{ }^{-1}$ in wastewater effluent has previously been reported in another Finnish WWTP, at the Turku Kakolanmäki WWTP (Turku, Finland) [28]. It has previously been detected at concentrations of 0.615 and $0.2 \mu \mathrm{g} \mathrm{L}^{-1}$ in the Viskan river at Jössabron Borås, in Sweden [34]. In Norwegian surface water sample concentrations of up to $0.05 \mu \mathrm{g} \mathrm{L}^{-1}$ and up to $1.9 \mu \mathrm{g} \mathrm{L}-1$ 
in treated wastewater [35] were detected. Deblonde et al. [1] presented in their review furosemide concentrations of $0.413 \mu \mathrm{g} \mathrm{L}^{-1}$ and $0.166 \mu \mathrm{g} \mathrm{L}^{-1}$ in wastewater influent and effluent, respectively. Among human pharmaceuticals divided into six categories (IA, IB, IIA, IIB, III, IV), furosemide belongs to the highest risk group (IA) as it has been shown to pose a risk to the aquatic environment already at concentrations of potential exposure (PEC) $>0.1 \mu \mathrm{g} \mathrm{L}^{-1}$ [36]. In the study by Jelic et al. (2011) removal rates for furosemide were found between WWTPs to be $30 \%, 60 \%$ and $80 \%$ [37]. In our experiment, $99.7 \%$ of furosemide was removed with ozone purification with the OxTube hermetic dissolution method and 5.9\% using PAA and UV disinfection. With the treatment of $\mathrm{H}_{2} \mathrm{O}_{2}$ and UV disinfection, no reduction was detected. Thus furosemide was successfully removed from the wastewater effluent with using ozone as the disinfection method.

\subsection{Lamotrigine}

Lamotrigine is an anticonvulsant medication used to treat epilepsy and bipolar disorder. Lamotrigine has recently been recognized as a persistent pharmaceutical in the water environment and in wastewater effluent. Bollman et al. [38], found N2-glucuronide conjugates of lamotrigine cleaved to form lamotrigine and that the concentration of lamotrigine increased from 1.1 to $1.6 \mu \mathrm{g} \mathrm{L}^{-1}$ in WWTPs. In this study, the lamotrigine concentration in wastewater was within the range of $1.5 \pm 0.06 \mu \mathrm{g} \mathrm{L}^{-1}$. In a previous study [39], it was found to be present in $94 \%$ of the studied wastewater samples, with a mean concentration of $0.488 \mu \mathrm{g} \mathrm{L}^{-1}$. The same study found lamotrigine in two drinking water samples. As lamotrigine has also been detected in groundwater, it has been suggested that lamotrigine could be used as an indicator for the presence of treated wastewater in raw water used for drinking water production [38]. Lamotrigine is very persistent chemically and physically and can resist UV photolysis and ozone, but it reacts rapidly with hydroxyl radicals. Therefore, advanced oxidation processes might be effective for removing this compound during water treatment [40]. In this study, 46.4\% of lamotrigine was removed by ozone purification with the OxTube hermetic dissolution method. With PAA and UV disinfection there was no reduction and with $\mathrm{H}_{2} \mathrm{O}_{2}$ and $\mathrm{UV}$ disinfection the reduction was $6.7 \%$. The removal capacity of the ozone disinfection was less efficient for lamotrigine than for other anthropogenic substances studied. However, ozone disinfection was more efficient for removal of lamotrigine than any other tested disinfection method.

\subsection{Diclofenac}

Diclofenac (2-2-2,6-dichlorophenylaminophenylacetic acid; DCF) is a common nonsteroidal anti-inflammatory drug that is used as oral tablets or as a topical gel. It is especially known for its harmful effects on vultures [41,42]. DCF is commonly found in municipal wastewater in Finland [43]. In 2002, the average concentration of DCF in wastewater influents was $0.35 \pm 0.1 \mu \mathrm{g} \mathrm{L}{ }^{-1}$ [44]. In 2013, DCF was selected for inclusion on the watch list of the WFD in order to collect data on it for the determination of risk reduction measures. According to the proposed EQS document, the maximum allowable concentrations of DCF is $0.1 \mu \mathrm{g} \mathrm{L}^{-1}$ in fresh waters and $0.01 \mu \mathrm{g} \mathrm{L}^{-1}$ in marine waters [45].

In recent years, the highest detected concentration of DCF in wastewater effluents in Finland has been $0.62 \mu \mathrm{g} \mathrm{L}^{-1}$ [46] and in surface waters 0.022 and $0.05 \mu \mathrm{g} \mathrm{L}{ }^{-1}$ [10]. Furthermore, Lindholm-Lehto et al. [43] found some high concentrations of DCF. In this study, $1.4 \pm 0.2 \mu \mathrm{g} \mathrm{L}^{-1}$ DCF was detected in the Kuopio wastewater effluent. Even though DCF is removed by natural processes such as photodegradation, the residues still remain in the environment as potential toxic metabolites and as the original compound. In the environment DCF is detected in lower concentrations, such as $\mathrm{ng} \mathrm{L}^{-1}$ to $\mathrm{mg} \mathrm{L}^{-1}$, than in wastewater. It has been stated that DCF has adverse effects on several environmental species already at concentrations of $\leq 1 \mu \mathrm{g} \mathrm{L} \mathrm{L}^{-1}$ [47]. It has been suggested that DCF used as an NSAID (non-steroidal anti-inflammatory drug) and as a pain gel cannot be removed effectively in WWTPs. The removal efficiencies of diclofenac in WWTPs varied from $0 \%$ up to $80 \%$, but were in mainly in the range of $21-40 \%$ in the study by Zhang et al. 
(2008) [48]. In our current study, DCF removal from the tested wastewater was 99.7\% using ozone purification with the OxTube hermetic dissolution method. PAA and UV disinfection removed $7.1 \%$ and with $\mathrm{H}_{2} \mathrm{O}_{2}$ and UV disinfection the reduction of DCF was $16.7 \%$. Diclofenac was efficiently removed from the wastewater effluent by using the ozone disinfection. Also, the combined $\mathrm{H}_{2} \mathrm{O}_{2}$ and UV disinfection was able to remove diclofenac more efficiently compared to the other studied substances.

\subsection{Venlafaxine}

Venlafaxine is one of the most abundant antidepressants in municipal wastewaters where concentrations of the substance have been generally shown to range between 0.003 and $0.743 \mu \mathrm{g} \mathrm{L}^{-1}$ wastewater effluent receiving waters [49]. In this study concentrations of $1.0 \pm 0.13 \mu \mathrm{g} \mathrm{L}^{-1}$ were found. Venlafaxine has also been detected at very low $\left(<0.005 \mu \mathrm{g} \mathrm{L}^{-1}\right)$ concentrations in untreated drinking water [50]. More than $60 \%$ of venlafaxine has successfully been removed with anaerobic biological reactors [51]. Ozone purification with the OxTube hermetic dissolution method removed $91.3 \%$ of the detected venlafaxine. $\mathrm{H}_{2} \mathrm{O}_{2}$ and UV disinfection removed $1.1 \%$, and with PAA and UV disinfection there was no reduction. In this study, venlafaxine was removed efficiently from the wastewater effluent by using ozone disinfection.

\subsection{Losartan}

Losartan, an antihypertensive, was one of the 10 most used medicines in Finland in 2018 [52]. Losartan can undergo structural modification resulting in formation of valsartan acid, which is a persistent pollutant ending up into activated sludge [53]. Losartan can also be found in various water matrices such as surface water and rivers [54]. It has been shown to be present in municipal wastewaters, e.g., in Colombia losartan has been detected in wastewater effluent at concentrations of 1.97 and $1.00 \mu \mathrm{g} \mathrm{L}^{-1}$ [55]. When studying pharmaceutical residues, Kot-Wask et al. (2016) found signs of losartan in wastewater from the Pomerania area in Poland [56]. In this study, a mean concentration of $0.9 \pm 0.2 \mu \mathrm{g} \mathrm{L}^{-1}$ was detected. The removal of losartan has been studied with a WWTP that was designed for biological nitrogen removal and chemical precipitation of phosphorus. The removal efficiency of losartan in the system varied between 50-80\% [57]. In our current study $99.6 \%$ of losartan was removed using ozone purification with the OxTube hermetic dissolution method. With PAA and UV disinfection, and $\mathrm{H}_{2} \mathrm{O}_{2}$ and UV disinfection the reduction was $13.8 \%$ and zero, respectively. Thus, the disinfection method using ozone as a disinfectant worked well in removal of losartan. Partial losartan reduction was also achieved with combined PAA and UV disinfection.

\subsection{The Most Efficient Removal of Anthropogenic Substances Achieved by Using Ozone Purification with OxTube Hermetic Dissolution Method}

Dissolved ozone has been used for years to disinfect and purify water [58]. Ozone is produced by separating oxygen from the air with an oxygen generator or industrial bottled instrument oxygen gas $\mathrm{O}_{2}$. Pure oxygen is passed through a strong electric field with continuous corona discharge. When ozone decomposes in water, the hydrogen peroxy $\left(\mathrm{HO}_{2}\right)$ and hydroxyl $(\mathrm{OH})$ are formed and they have great oxidizing capacity $[59,60]$. The half-life of ozone in aqueous solution depends, among other things, on $\mathrm{pH}$ and temperature of the water. In our study, the usage of ozone with the OxTube hermetic dissolution method was relatively efficient in removing of the detected anthropogenic substances. The reason for the achieved reduction capacities could be due to free radicals that are formed.

The use of ozone-based cleaning and disinfecting agents has increased in recent years in industry and water treatment sectors. The advantage of ozone compared to chlorine or other disinfectants is that ozone is very reactive, degrades rapidly and leaves no toxic or unwanted end products. It is an exceptionally good disinfectant with faster disinfection kinetics and more potency to eliminate most microorganisms than other chemical disinfectants in use. Ozonation followed by chlorination is proved to be better in terms of producing less disinfection byproducts than the sole use of chlorination [61]. 
Wastewater is a complex mixture of water and various substances, its viscosity is usually higher than water, the movement between substances is slow and thus its handling differs greatly from e.g., domestic water. This may be one reason why using OxTube hermetic dissolution method produced such good results in our case although we did not test the efficiency of ozone disinfection without this device.

\section{Conclusions}

Many anthropogenic substances are harmful to the environment. Out of the 121 analysed substances 44 were detected (Table S1) in the treated wastewater samples collected from the Kuopio (Lehtoniemi) WWTP. Eight substances (cetirizine, BZT, hydrocholorothiazide, furosemide, lamotrigine, DFC, venlafaxine, and losartan) were detected at concentrations over $1 \mu \mathrm{g} \mathrm{L}^{-1}$. Among these eight substances, DCF is the only one that appears on the European Union's WFD monitoring list. In 2013, it was included on the first watch list to gather monitoring data for the purpose of facilitating the determination of appropriate measures to address the risk posed by the substance.

The results from this study showed that ozone disinfection using an OxTube hermetic dissolution method can efficiently reduce the concentration of pharmaceuticals in wastewater effluent. In future work, the OxTube hermetic dissolution method should be compared to other ozone mixing devices to prove the performance and capacity of this novel dissolution technique.

Supplementary Materials: The following are available online at https:/ /www.mdpi.com/2073-444 1/13/3/360/s1, Figure S1: Equipment used in the experiments; Table S1: List of the concentrations of analysed anthropogenic substances

Author Contributions: J.I.; writing — original draft preparation, I.N.; project administration, writingreview and editing, M.N. and A.-M.H. writing-review and editing, T.P. and I.T.M. supervision, writing-review and editing E.A. and I.T.M.; funding acquisition. All authors have read and agreed to the published version of the manuscript.

Funding: This study was funded by the European Regional Development (A72637).

Institutional Review Board Statement: Not applicable.

Informed Consent Statement: Not applicable.

Data Availability Statement: Not applicable.

Acknowledgments: This study was part of the project "Fostering market penetration and implementation of combined use of low energy Led-UV -technologies and PAA-chemicals in water disinfection". The authors thank the staff of the Savonia University of Applied Sciences, in Kuopio, Finland, and the staff of the Finnish Institute for Health and Welfare.

Conflicts of Interest: The authors declare no conflict of interest.

\section{References}

1. Deblonde, T.; Cossu-Leguille, C.; Hartemann, P. Emerging pollutants in wastewater: A review of the literature. Int. J. Hyg. Environ. Health 2011, 214, 442-448. [CrossRef] [PubMed]

2. Martín-Pozo, L.; De Alarcón-Gómez, B.; Rodríguez-Gómez, R.; García-Córcoles, M.T.; Çipa, M.; Zafra-Gómez, A. Analytical methods for the determination of emerging contaminants in sewage sludge samples. A review. Talanta 2019, 192, 508-533. [CrossRef] [PubMed]

3. Thomaidis, N.S.; Asimakopoulos, A.G.; Bletsou, A. Emerging contaminants: A tutorial mini-review. Glob. NEST J. 2012, 14, 72-79.

4. Gros, M.; Petrović, M.; Ginebreda, A.; Barceló, D. Removal of pharmaceuticals during wastewater treatment and environmental risk assessment using hazard indexes. Environ. Int. 2010, 36, 15-26. [CrossRef]

5. Song, P.; Huang, G.; An, C.; Xin, X.; Zhang, P.; Chen, X.; Ren, S.; Xu, Z.; Yang, X. Exploring the decentralized treatment of sulfamethoxazole-contained poultry wastewater through vertical-flow multi-soil-layering systems in rural communities. Water Res. 2021, 188, 116480. [CrossRef]

6. Lienert, J.; Güdel, K.; Escher, B.I. Screening Method for Ecotoxicological Hazard Assessment of 42 Pharmaceuticals Considering Human Metabolism and Excretory Routes. Environ. Sci. Technol. 2007, 41, 4471-4478. [CrossRef] 
7. Kosonen, J.; Kronberg, L. The occurrence of antihistamines in sewage waters and in recipient rivers. Environ. Sci. Pollut. Res. 2009, 16, 555-564. [CrossRef]

8. European Union. Water Framework Directive (WFD) 2000/60/EC: Directive 2000/60/EC of the European Parliament and of the Council of 23 October 2000 Establishing a Framezork for Community Action in the Field of Water Policy; European Union: Brussels, Belgium, 2012.

9. European Union. Directive 2013/39/EU of the European Parliament and of the Council of 12 August 2013 Amending Directives 2000/60/EC and 2008/105/EC as Regards Priority Substances in the Field of Water Policy; European Union: Brussels, Belgium, 2013.

10. Vieno, N.; Äystö, L.; Mehtonen, J.; Sikanen, T.; Karlsson, S.; Fjäder, P.; Nystén, T. Lääkejäämien vesistöriskien arviointi Suomessa. Vesitalous 2020, 1, 25-28. (In Finnish)

11. Mejía-Morales, C.; Hernández-Aldana, F.; Cortes-Hernandez, D.M.; Rivera-Tapia, J.A.; Castañeda-Antonio, D.; Bonilla, N. Assessment of Biological and Persistent Organic Compounds in Hospital Wastewater After Advanced Oxidation Process UV/H2O2/O3. Waterairsoil Pollut. 2020, 231, 1-10. [CrossRef]

12. Chen, X.; Huang, G.; Li, Y.; An, C.; Feng, R.; Wu, Y.; Shen, J. Functional PVDF ultrafiltration membrane for Tetrabromobisphenol-A (TBBPA) removal with high water recovery. Water Res. 2020, 181, 115952. [CrossRef]

13. Zhao, Y.; Huang, G.; An, C.; Huang, J.; Xin, X.; Chen, X.; Hong, Y.; Song, P. Removal of Escherichia Coli from water using functionalized porous ceramic disk filter coated with Fe/TiO2 nano-composites. J. Water Process. Eng. 2020, 33, 101013. [CrossRef]

14. EPA. Method 1694: Pharmaceuticals and Personal Care Products in Water, Soil, Sediment, and Biosolids by HPLC/MS/MS; Environmental Protection Agency: Washington, DC, USA, 2007.

15. Zhang, L.; Cheng, L.; Hong, J. The Clinical Use of Cetirizine in the Treatment of Allergic Rhinitis. Pharmacology 2013, 92, 14-25. [CrossRef] [PubMed]

16. Curran, M.P.; Scott, L.J.; Perry, C.M. Cetirizine. Drugs 2004, 64, 523-561. [CrossRef]

17. Teixeira, M.; Almeida, Â.; Calisto, V.; Esteves, V.I.; Schneider, R.J.; Wrona, F.J; Soares, A.M.; Figueira, E.; Freitas, R. Toxic effects of the antihistamine cetirizine in mussel Mytilus galloprovincialis. Water Res. 2017, 114, 316-326. [CrossRef]

18. Bahlmann, A.; Carvalho, J.J.; Weller, M.G.; Panne, U.; Schneider, R.J. Immunoassays as high-throughput tools: Monitoring spatial and temporal variations of carbamazepine, caffeine and cetirizine in surface and wastewaters. Chemosphere 2012, 89, 1278-1286. [CrossRef]

19. Ma, D.; Chen, L.; Liu, R. Removal of novel antiandrogens identified in biological effluents of domestic wastewater by activated carbon. Sci. Total. Environ. 2017, 595, 702-710. [CrossRef]

20. Cantwell, M.G.; Sullivan, J.C.; Burgess, R.M. Benzotriazoles: History, environmental distribution, and potential ecological effects. In Anonymous Comprehensive Analytical Chemistry; Elsevier: Amsterdam, The Netherlands, 2015; pp. 513-545.

21. Muschietti, A.; Serrano, N.; Ariño, C.; Diaz-Cruz, M.S.; Cruz, J.M.D. Screen-Printed Electrodes for the Voltammetric Sensing of Benzotriazoles in Water. Sensors 2020, 20, 1839. [CrossRef]

22. Janna, H.; Scrimshaw, M.D.; Williams, R.J.; Churchley, J.; Sumpter, J.P. From Dishwasher to Tap? Xenobiotic Substances Benzotriazole and Tolyltriazole in the Environment. Environ. Sci. Technol. 2011, 45, 3858-3864. [CrossRef]

23. Hart, D.; Davis, L.; Erickson, L.; Callender, T. Sorption and partitioning parameters of benzotriazole compounds. Microchem. J. 2004, 77, 9-17. [CrossRef]

24. Alotaibi, M.D.; McKinley, A.J.; Patterson, B.M.; Reeder, A.Y. Benzotriazoles in the Aquatic Environment: A Review of Their Occurrence, Toxicity, Degradation and Analysis. Waterairsoil Pollut. 2015, 226, 226. [CrossRef]

25. Loos, R.; Carvalho, R.; António, D.C.; Comero, S.; Locoro, G.; Tavazzi, S.; Paracchini, B.; Ghiani, M.; Lettieri, T.; Blaha, L.; et al. EU-wide monitoring survey on emerging polar organic contaminants in wastewater treatment plant effluents. Water Res. 2013, 47, 6475-6487. [CrossRef] [PubMed]

26. Fernández-Perales, M.; Sánchez-Polo, M.; Rozalen, M.; López-Ramón, M.V.; Mota, A.; Rivera-Utrilla, J. Degradation of the diuretic hydrochlorothiazide by UV/Solar radiation assisted oxidation processes. J. Environ. Manag. 2020, 257, 109973. [CrossRef] [PubMed]

27. Ranjan, S.; Devarapalli, R.; Kundu, S.; Vangala, V.R.; Ghosh, A.; Reddy, C.M. Three new hydrochlorothiazide cocrystals: Structural analyses and solubility studies. J. Mol. Struct. 2017, 1133, 405-410. [CrossRef]

28. ̈̈ystö, L.; Mehtonen, J.; Kalevi, K. Kartoitus Lääkeaineista Yhdyskuntajätevedessä ja Pintavedessä; Finnish Environment Institute: Helsinki, Finland, 2014. (In Finnish)

29. Oosterhuis, M.; Sacher, F.; Ter Laak, T.L. Prediction of concentration levels of metformin and other high consumption pharmaceuticals in wastewater and regional surface water based on sales data. Sci. Total. Environ. 2013, 442, 380-388. [CrossRef] [PubMed]

30. Bueno, M.M.; Gomez, M.; Herrera, S.; Hernando, M.; Agüera, A.; Fernández-Alba, A.R.R. Occurrence and persistence of organic emerging contaminants and priority pollutants in five sewage treatment plants of Spain: Two years pilot survey monitoring. Environ. Pollut. 2012, 164, 267-273. [CrossRef]

31. Radjenovic, J.; Petrovic, M.; Barceló, D. Analysis of pharmaceuticals in wastewater and removal using a membrane bioreactor. Anal. Bioanal. Chem. 2006, 387, 1365-1377. [CrossRef]

32. Laurencé, C.; Rivard, M.; Martens, T.; Morin, C.; Buisson, D.; Bourcier, S.; Sablier, M.C.; Oturan, M.A. Anticipating the fate and impact of organic environmental contaminants: A new approach applied to the pharmaceutical furosemide. Chemosphere 2014, 113, 193-199. [CrossRef] 
33. Fimea, K. Finnish Statistics on Medicines. 2016. Available online: http://urn.fi/URN:NBN:fi-fe2017111750773 (accessed on 2 December 2020).

34. Khalaf, H.; Salste, L.; Karlsson, P.; Ivarsson, P.; Jass, J.; Olsson, P.-E. In vitro analysis of inflammatory responses following environmental exposure to pharmaceuticals and inland waters. Sci. Total. Environ. 2009, 407, 1452-1460. [CrossRef]

35. TemaNord. PPCP Monitoring in the Nordic Countries—Status Report; Nordic Council of Ministers: Copenhagen, Denmark, 2012; p. 519.

36. Besse, J.-P.; Garric, J. Human pharmaceuticals in surface waters: Implementation of a prioritization methodology and application to the French situation. Toxicol. Lett. 2008, 176, 104-123. [CrossRef]

37. Jelic, A.; Gros, M.; Ginebreda, A.; Cespedes-Sánchez, R.; Ventura, F.; Petrovic, M.; Barcelo, D. Occurrence, partition and removal of pharmaceuticals in sewage water and sludge during wastewater treatment. Water Res. 2011, 45, 1165-1176. [CrossRef]

38. Bollmann, A.F.; Seitz, W.; Prasse, C.; Lucke, T.; Schulz, W.; Ternes, T. Occurrence and fate of amisulpride, sulpiride, and lamotrigine in municipal wastewater treatment plants with biological treatment and ozonation. J. Hazard. Mater. 2016, 320, 204-215. [CrossRef] [PubMed]

39. Ferrer, I.; Thurman, E.M. Identification of a New Antidepressant and its Glucuronide Metabolite in Water Samples Using Liquid Chromatography/Quadrupole Time-of-Flight Mass Spectrometry. Anal. Chem. 2010, 82, 8161-8168. [CrossRef] [PubMed]

40. Keen, O.S.; Ferrer, I.; Thurman, E.M.; Linden, K.G. Degradation pathways of lamotrigine under advanced treatment by direct UV photolysis, hydroxyl radicals, and ozone. Chemosphere 2014, 117, 316-323. [CrossRef]

41. Richards, N.; Gilbert, M.; Taggart, M.; Naidoo, V. A Cautionary Tale: Diclofenac and Its Profound Impact on Vultures. Encycl. Anthr. 2018, 247-255. [CrossRef]

42. Sathishkumar, P.; Meena, R.A.A.; Palanisami, T.; AshokKumar, V.; Palvannan, T.; Gu, F.L. Occurrence, interactive effects and ecological risk of diclofenac in environmental compartments and biota - a review. Sci. Total. Environ. 2020,698, 134057. [CrossRef]

43. Lindholm-Lehto, P.C.; Ahkola, H.S.J.; Knuutinen, J.S.; Herve, S.H. Widespread occurrence and seasonal variation of pharmaceuticals in surface waters and municipal wastewater treatment plants in central Finland. Environ. Sci. Pollut. Res. 2016, 23, 7985-7997. [CrossRef] [PubMed]

44. Lindqvist, N.; Tuhkanen, T.; Kronberg, L. Occurrence of acidic pharmaceuticals in raw and treated sewages and in receiving waters. Water Res. 2005, 39, 2219-2228. [CrossRef]

45. Lonappan, L.; Brar, S.K.; Das, R.K.; Verma, M.; Surampalli, R.Y. Diclofenac and its transformation products: Environmental occurrence and toxicity - A review. Environ. Int. 2016, 96, 127-138. [CrossRef] [PubMed]

46. Vieno, N. Occurrence of pharmaceuticals in Finnish sewage treatment plants, surface waters, and their elimination in drinking water treatment processes. 2007. Available online: http:/ / urn.fi/URN:NBN:fi:tty-200810021012 (accessed on 11 December 2020).

47. Vieno, N.; Sillanpää, M. Fate of diclofenac in municipal wastewater treatment plant — A review. Environ. Int. 2014, 69, 28-39. [CrossRef]

48. Zhang, Y.; Geissen, S.-U.; Gal, C. Carbamazepine and diclofenac: Removal in wastewater treatment plants and occurrence in water bodies. Chemosphere 2008, 73, 1151-1161. [CrossRef]

49. Thompson, W.A.; Vijayan, M.M. Environmental levels of venlafaxine impact larval behavioural performance in fathead minnows. Chemosphere 2020, 259, 127437. [CrossRef] [PubMed]

50. Metcalfe, C.D.; Chu, S.; Judt, C.; Li, H.; Oakes, K.D.; Servos, M.R.; Andrews, D.M. Antidepressants and their metabolites in municipal wastewater, and downstream exposure in an urban watershed. Environ. Toxicol. Chem. 2010, 29, 79-89. [CrossRef] [PubMed]

51. Falås, P.; Wick, A.; Castronovo, S.; Habermacher, J.; Ternes, T.A.; Joss, A. Tracing the limits of organic micropollutant removal in biological wastewater treatment. Water Res. 2016, 95, 240-249. [CrossRef] [PubMed]

52. Fimea/Kela, 2018. Finnish statistics of medicines. Available online: http://urn.fi/URN:NBN:fi-fe2019123149481 (accessed on 2 December 2020).

53. Kaur, B.; Dulova, N. UV-assisted chemical oxidation of antihypertensive losartan in water. J. Environ. Manag. 2020, 261, 110170. [CrossRef] [PubMed]

54. Carpinteiro, I.; Castro, G.; Rodríguez, I.; Cela, R. Free chlorine reactions of angiotensin II receptor antagonists: Kinetics study, transformation products elucidation and in-silico ecotoxicity assessment. Sci. Total. Environ. 2019, 647, 1000-1010. [CrossRef]

55. Botero-Coy, A.; Martínez-Pachón, D.; Boix, C.; Rincón, R.; Castillo, N.; Arias-Marín, L.; Manrique-Losada, L.; Torres-Palma, R.; Moncayo-Lasso, A.; Hernández, F.H. An investigation into the occurrence and removal of pharmaceuticals in Colombian wastewater. Sci. Total. Environ. 2018, 642, 842-853. [CrossRef] [PubMed]

56. Kot-Wasik, Á.; Jakimska, A.; Śliwka-Kaszyńska, M. Occurrence and seasonal variations of 25 pharmaceutical residues in wastewater and drinking water treatment plants. Environ. Monit. Assess. 2016, 188, 661. [CrossRef]

57. Gurke, R.; Rößler, M.; Marx, C.; Diamond, S.; Schubert, S.; Oertel, R.; Fauler, J. Occurrence and removal of frequently prescribed pharmaceuticals and corresponding metabolites in wastewater of a sewage treatment plant. Sci. Total. Environ. 2015, 532, 762-770. [CrossRef]

58. Bustos, Y.; Vaca, M.; López, R.; Bandala, E.; Torres, L.; Rojas-Valencia, N. Disinfection of Primary Municipal Wastewater Effluents Using Continuous UV and Ozone Treatment. J. Water Resour. Prot. 2014, 6, 16-21. [CrossRef]

59. Tchobanoglous, G. Wastewater Engineering: Treatment and Resource Recovery. McGraw-Hill 2014, 2, $1367-1377$. 
60. US EPA. Wastewater Technology Fact Sheet, Ozone Disinfection; US EPA: Washington, DC, USA, 2009.

61. Hu, J.Y.; Wang, Z.S.; Ng, W.J.; Ong, S.L. Disinfection By-Products in Water Produced by Ozonation and Chlorination. Environ. Monit. Assess. 1999, 59, 81-93. [CrossRef] 